\title{
DE HANDHAVING DER ORDE EN TUCHT OP DE SCHEPEN DER OOST-INDISCHE COMPAGNIE.
}

door Dr. J. DE HULLU.

Tenzij de schippers en andere scheepsofficieren, gelijk maar al te dikwijls voorkwam, het opleggen van straffen eigenmachtig geheel aan zich trokken ${ }^{1}$, geschiedde de rechtspraak op de schepen der Compagnie in naam der Hooge Overheid ${ }^{2}$ door den Scheepsraad, den Breeden Raad en den Krijgsraad.

Over vergrijpen op welke geldboeten of lichte lijfstraffen stonden, de zoogenaamde civiele misbruiken en overtredingen, vonnisten de opperkoopman, onderkoopman, schipper en eenige andere hoofdbevelhebbers, die te zamen den Dagelijkschen-, Particulieren- of Scheepsraad uitmaakten van den bodem, daar zij waren voorgevallen ${ }^{3}$. Vóór de Scheepsraad echter met de

1 Bij resolutie Zeventien 8 Aug. 1705 werd aan de schippers en verdere scheepsopperhootden, „die zich veeltijds aanmatigen om over deze en gẹne misdrijven en delicten contrarie de ordres van de Compagnie op eigen autoriteit, zonder convocatie of kennis van den Scheeps- of Breeden Raad, na gelegenheid straf en correctie bij forme van justitie te oefenen", op het gestrengst verboden zulks te doen op verbeurte van zes maanden gage voor de eerste maal en op straffe, indien zij er zich voor de tweede maal aan schuldig maakten, van inhabiel en onbekwaam te worden verklaard om de Compagnie verder te dienen.

2 Scheepsboek Sparenrijk 1748; Vonnis Breede Raad der retourvloot 21 Maart 1635. Ook komt voor: in naam van de Staten-Generaal (Breede Rand retourvloot 26 Juni 1634, Scheepsboek Zuiderbeek 1715, Journaal uitgaand schip Zutphen 15 Mei 1632), in naam van de Staten van Holland en Westfriesland en de Bewindhebbers der Compagnie (Scheepsboek Bentvelt 1715), in naam van de Staten Generaal, den Prins van Oranje en Gouverneur Generaal en Raden (Scheepsboek Crabbendijk 1749), in naam van de Staten-Generaal en de Prinses-Weduwe als voogdes van den Erfstadhouder (Scheepsboek Renswoude 1757).

${ }^{3}$ Instructiën Scheepsraad van 7 Dec. 1619, 26 Oct. 1635, Sept. 1649; Artikelbrieven van 16 Oct. 1619, 2 Maart 1634, 8 Maart 1658, 3 Sept. 1672, 4 Sept, 1742. Volgens de instructiën van 1619, 1635 en 1649 moest de Scheeps- 
behandeling van een geding aanving, was de koopman of de schipper gehouden zich daags te voren met zijn schip dicht bij dat van den kommandeur der vloot te vervoegen en hem van de voorgenomen rechtszitting te verwittigen door een uur lang de vlag aan de kraallijn bij de mars ${ }^{1}$ te laten waaien, opdat hij haar desverkiezende hetzij in eigen persoon hetzij door een gemachtigde zou kunnen komen bijwonen en presideeren. En de Scheepsraad mocht den volgenden dag niet eerder met de zaak voortvaren dan nadat men tot des middags toe op zijn komst had gewacht ${ }^{2}$. Hetzelfde sein moest worden gegeven wanneer de voorzitter en twee leden van den Scheepsraad een bij hen aangebracht feit "crimineel of kapitaal» oordeelden ${ }^{3}$. Over de kapitale of crimineele misdrijven toch, dat wil zeggen

raad bestaan uit vijf personen n.l. den opperkoopman, den schipper, den onderkoopman, den opperstuurman en den hoogbootsman, en het voorzitterschap worden waargenomen door den kommies of koopman. Bij resolutie Zeventien 5 Mei 1661 was bepaald dat in den Scheepsraad zouden compareeren: op een groot schip de koopman, schipper, opperstuurman, assistent en hoogbootsman of wel de schipper, onderkoopman, opperstuurman, assistent en hoogbootsman, en op een klein schip, fluit of jacht de schipper, de assistent zoo deze ten minste van competente capaciteit en ouderdom was, de opperstuurman, de onderstuurman en de hoogbootsman. Kolbe in zijn Beschrijving van de Kaap, Amst. 1727, blz. 27, geeft op dat de Scheepsraad samengesteld was uit den kapitein, boekhouder, opperstuurman, bootsman, schieman, onderbootsman, onderschieman, konstapel en bottelier. Volgens den artikelbrief van 1742 moesten als leden fungeeren de schipper, door wien het presidium werd bekleed, de oudste luitenant, de onderkoopman, of assistent, de tweede of jongste luitenant en de opperstuurman, en op schepen, waarop geen luitenants voeren, de schipper, onderkoopman of assistent, opperstuurman, onderstuurman en hoogbootsman. Volgens Nicolaas de Graaff, Oost-Indise Spiegel, blz. 34 werd de Scheepsraad nsoms ook versterkt" met de kwartiermeesters "vermits deze het meest onder het scheepsvolk verkeerden en derzelver gedachten haar het beste bekend" waren.

1 De kraallijn is een lijn, waaraan houten kralen geregen zijn en die, om den mast aan den klauw van den gaffel vastgemaakt, dient om deze bij het ophijschen of strijken tegen den mast te houden", (Van Lennep, Zeemanswoordenboek in voce). De mars is het, houten vlak, zich rondom den mast uitstrekkende, ter plaatse waar de hoofdtouwen gespannen worden" (a. w. in voce).

2 Instructiën Scheepsraad van 1619, 1635, 1649.

s Joost de Damhoudere, Practijcke in criminele saken, Rotterdam 1660, blz. 4: "de capitale (crimen) zijn degenen, die men punieert capitalijck of lijvelijck metter doodt of metten eeuwigen banne of met der confiscatie van goede. Die niet en zijn capitale zijn degenen, die men punieert met gelde of eenige cleijne punitie corporelle". 
die waarop de dood of een andere zware straf was gesteld, kwam de beslissing alleen toe aan een op het schip van den kommandeur te houden vereenigde zitting van den Scheepsraad en de gezamenlijke kooplieden, schippers, onderkooplieden en opperstuurlieden, of met andere woorden aan den Breeden Raad van de gansche vloot ${ }^{1}$. Voer een schip niet in eskader maar op zichzelf, dan wees de Scheepsraad vonnis over alle voorgevallen misdaden en vergrijpen hoe ook genaamd ${ }^{2}$. Ten opzichte van de soldaten was in de artikelbrieven verordend dat alle zaken hen aangaande behoorden te worden afgedaan bij den krijgsraad, dat is "bij den koopman, schipper, sergeant of hoogeren krijgsofficier, korporaal en landspassaat», met dien verstande nochtans dat zaken van "geheel zwaren gewichte, zoo wanneer daar twee of meer schepen in vlote bij malkanderen» waren, behandeld moesten worden bij den Breeden Raad ${ }^{3}$. Alle aanklachten, sententiën en executiën moesten "pertinentelijk» in een register worden geboekt ${ }^{4}$. De beslissing geschiedde bij meerderheid van stemmen 5 .

1 Instructiën Breede Raad van 7 Dec. 1619, 26 Oct. 1635, Sept. 1649. Volgens de anngehaalde Breede Raads-instructiën waren leden: al de kooplieden of commiezen der respective schepen, al de schippers, al de onderkooplieden en al de opperstuurlieden; volgens de artikelbrieven van 1619, 1634, 1658 en 1672 bestond de Breede Raad uit al de kooplieden of commiezen, al de schippers, al de onderkooplieden, al de opperstuurlieden en al de sergeanten of andere hoogere officieren, die in de respective schepen waren, en was de kommandeur der vloot voorzitter van het college. De artikelbrief van 1742 bepaalde dat, als vijf of meer schepen bij elkander zeilden, in den Breeden Raad alleen zitting zouden hebben de kommandeur als president, de schippers van de schepen, benevens de eerste luitenant en de onderkoopman of boekhouder van het kommandeursschip, die tevens de pen moest voeren. Telde de vloot minder dan vijf schepen, dan moesten nevens de gezagroerders der schepen nog zooveel anderen van de eerste officieren der schepen "daarin worden beroepen", dat zij met den kommandeur of bevelhebber te zamen een getal van zeven personen uitmaakten.

2 Nicolaas de Graaff, a. w. blz. 34 .

s Artikelbrieven van $1619,1634,1658,1672$. In die van 1742 komt deze bepaling niet voor.

4 Instructiën Scheepsraad van 1619, 1635, 1649. De Breede Raadsinstructiën van diezelfde jaren spreken alleen van de verplichting tot het registreeren der besluiten, waarin echter de sententiën ongetwijfeld mede zijn begrepen geweest.

${ }^{5}$ Instructiën Scheepsraad als voren. De Breede Raads-instructiën van 1619, 1635,1649 en de in 1790 te Middelburg gedrukte bepalen, dat alles zou beslist worden bij meerderheid van stemmen, met dien verstande dat bij staking van stemmen de president een dubbele stem zou hebben. Doch dit laatste mocht geen plaats hebben in zaken van justitie volgens den artikelbrief van 1742 . 
In gevallen van bijzonderen aard heeft het hoogstwaarschijnlijk van oudsher aan de scheepsoverheid vrij gestaan de beslissing over te laten aan de rechters in het vaderland of in Indië. De artikelbrief van 1742 , die zich op dit stuk duidelijker uitspreekt dan zijn voorgangers, handhaaft denkelijk slechts het bestaande gebruik als hij met zooveel woorden bepaalt, dat de scheepsrechters" in "kapitale of halszaken van veel duisterheid of die uitstel lijden konden», alleen informatiën behoefden te nemen en de delinquenten met de stukken te hunnen laste overgeven mochten, zoo het misdrijf op de thuisreize was voorgevallen; aan het Hof van Holland, zoo het op de uitreis was gepleegd, aan den ordinairen rechter van de plaats waarheen het schip was bestemd. Nadrukkelijk echter was hun zoowel in dezen als in alle oudere artikelbrieven voorgeschreven om, "bijaldien eenige conspiratiën of andere notoire halszaken in de uit- of wederomreize in de schepen mochten vallen», die dadelijk te berechten en te executeeren, "zonder gelijk als voor dezen gebeurd was de misdadigen tot groot perikel van .de schepen in apprehensie te houden om in Indië of naar huis te brengen en aldaar haar verdiende straffe te doen ontvangen ».» ${ }^{1}$

Hoofd van de politie en tegelijkertijd officier van justie was de provoost ${ }^{2}$. Hij zag toe dat de verordeningen van den artikelbrief werden nageleefd ${ }^{3}$, moest des avonds als de wacht zou aangaan dit over het schip uitroepen en gebieden dat men zich onthouden zou van dronkenschap en het maken van gerucht en geweld en dat ieder, die aan de beurt was om te waken, aan dek zou komen en dat de anderen te kooi zouden gaan ${ }^{4}$, zette hen die zich "crimineellijk verliepen» gevangen, trad bij procedures op als aanklager en eischer ${ }^{5}$ en was belast met de

1 Artikelbrieven van 1619, 1634, 1658, 1672, 1742.

2 In de eerste tijden, zegt Pieter van Dam in zijn Beschrijving der OostIndische Compagnie (Boek I Deel I cap. 18), wanneer de schepen van hier onder een admiraal afgingen was men gewoon een fiscaal daarover te stellen met een instructie, naderhand is die instructie aan de provoosten van ieder schip medegegeven.

3 Blijkens de instructiën voor den provoost in 1735 en 1788 te Middelburg gedrukt.

4 Nicolaas de Graaff, a.-w. blz. 29.

5 Instructiën provoost van 20 Dec. 1622 en de in 1735 en 1788 te Middelburg gedrukte; Instructiën Scheepsraad ran 1619, 1635, 1649 en de in 1790 te Middelburg gedrukte. 
ten uitvoerlegging van de vonnissen ', welke tenzij de Breede Raad anders beschikte plaats had op het schip, daar de misdaad was bedreven ${ }^{2}$. Aan emolumenten boven zijn gage ontving hij een zeker aandeel in sommige boeten alsmede van ieder, die in de boeien gesloten werd, het zoogenaamde sluitgeld, ten bedrage van zes stuiver van een mindere en tien stuiver van een officier ${ }^{3}$. Als waardigheidsteeken bezat hij een met oranjezijde linten versierden ${ }^{4}$ gerechtsstok, dien hij bij het afroepen van de wacht tegen den grooten mast sloeg ${ }^{5}$ en denkelijk, wanneer een vonnis werd ten uitvoer gelegd, als roede van justitie in de hand hield.

Over de vraag hoe de provoost bij de procedure handelde verspreiden de instructiën en artikelbrieven weinig of geen licht. Bij een geding over doodslag moest hij ten overstaan van twee rechters uit den scheepsraad, die de gezagvoerder daarvoor op zijn verzoek had aangewezen, eerst de getuigen en vervolgens den beklaagde ondervragen. $\mathrm{Na}$ afloop van het verhoor liet hij den beklaagde voorlezing doen van zijn in het confessieboek opgeteekende antwoorden en deze, ats hij ze gestand deed, zoowel door hem als door de twee rechters onderteekenen, en nam daarop het boek onder zijn bewaring om te beletten dat er zonder de voorkennis en toestemming van rechters en beklaagde eenige verandering in werd aangebracht. Indien de beklaagde het hem ten laste gelegde misdrijf loochende en de bewijzen voor zijn schuld "niet zoo klaar en sterk waren dat de provoost daarop mocht blijven, als te weten dat niemand gezien had dat de gevangene het feit gedaan had of dat de indiciën niet suffisant waren om daaruit vastelijk besloten te kunnen worden dat hij het feit gedaan had», mocht niettemin de provoost "zijn conclusie formeeren naar den tekst van den artikelbrief, daarbij voegende dat de gevangene arbitralijk aan den lijve, maandgelden en goederen gestraft en gemulcteerd zou worden, gelijk naar recht en justitie bevonden zou worden

1 Artikelbrieven van 1619, 1634, 1658, 1672, 1742.

' Instructiën Scheepsraad van 1619, 1635, 1649 en de in 1790 gedrukte.

3 Blijkens de artikelbrieven.

- Blijkens de Aanteekeningen van den Bewindhebber Arnoldus Buchelius gaf men in 1620 den provoost bij de monstering zijn stokken "alle met oraignie sijde banden".

5 Nicolaas de Graaff, a. w. blz. 29. 
te behooren. "Zoo echter niettegenstaande de ontkenning van den beklaagde diens schuld boven allen twijfel verheven was, dan moest de provoost, in overeenstemming met de toenmalige opvatting dat niemand ter dood kon worden veroordeeld tenzij hij met eigen mond zijn misdaad had beleden, eischen dat men hem ter pijniging zou brengen aleer hij zich met anderen kon beraden. ${ }^{1}$

Van het toepassen van pijniging op de Compagnieschepen vindt men zóó zelden melding gemaakt, dat het moeilijk is na te gaan hoe het daarbij toeging. Op de Naussausche vloot van Jacques L'Hermite en Geert Huijgen Schapenham, in 1623, liet men een opvarende, die van giftmengerij werd verdacht, "een van de zwaarste kamers aan het lijf hangen, " ${ }^{2}$ blijkbaar om hem door uitrekking van de ledematen te folteren evenals dat op de pijnbank geschiedde ${ }^{3}$. Een andere manier van pijnigen bestond hierin dat men den beklaagde lontjes tusschen de vingers legde, die vervolgens in brand werden gestoken ${ }^{4}$.

Wat aan boord voor misdrijf gold en welke straffen er werden opgelegd stond beschreven in den door de Staten-Generaal uitgevaardigden artikelbrief, die door alle bedienden van de Compagnie bezworen moest worden en, zoolang hun diensttijd duurde, voor hen van kracht bleef. Dat men op de schepen niets gedoogde wat tot kleinachting van de religie strekte sprak bij een althans uiterlijk zoo godsdienstig volk als de Nederlanders destijds waren haast van zelf. Wie Gods naam misbruikte met vloeken, zweren, "lasterlijke propoosten, gekkernijen of anderszins» beliep een boete van tien stuiver en "arbitrale correctie naar gelegenheid van de lasteringen, die gezeid en gesproken» waren, terwijl degenen, die den predikant, ziekentrooster of voorlezer van den bijbel berispten, beschimpten of in hun bediening bemoeilijkten of beletten, gestraft werden met arbitrale correctie. Bleef iemand zonder vergunning uit de godsdienstoefeningen weg dan verbeurde hij de eerste reis het wijnrantsoen en nog een gulden daarboven, de tweede maal het dubbele,

1 Instructiën provoost van 1622 en de in 1735 te Middelburg gedrukte.

- De kamer was dat gedeelte van een vuurwapen, waarin de buskruitlading kwam te liggen, hier is misschien sprake van scheepskanonnetjes.

3 Journaal van de Nassausche vloot in Begin en Voortg. II (12 Oct. 1623).

4 Sententie van 28 Maart 1649 in het Scheepsboek van het uitgaand schip Sparenrijk: goedgevonden een van diefstal beschuldigd matroos nacht lonten tusschen de vingers te stellen, hetwelk terstond geschiedde maar dezelve waren nog niet in brand gestoken of bekende terstond".

Dl. 67 . 
indien hij ze voor de derde maal verzuimde werd hij door het kwartier gelaarsd ${ }^{1}$.

Minder uit eerbied voor ieders persoonlijke overtuiging dan wel om de rust en vrede te handhaven was verder bepaald dat elk, die eenige quaestiën of disputen van religie opwierp, gestraft zou worden, telkens als het voorviel, met verlies van een maand gage; en zoo uit de twistgesprekken haat of twist voortsproot daarenboven nog met arbitrale correctie. Wie zich niet tevreden hield met het rantsoen, zooals dit door den Breeden Raad of Scheepsraad was bepaald, of ter sluiks eenigen wijn uit de provisie haalde verbeurde twee en die, onder voorwendsel dat zij niet goed was, eigenmachtig eenige victualie over boord wierp, ééne maand gage. Op het niet behoorlijk onderhouden van de wapenen, die men van wege de Compagnie ontving, stond verlies van een halve maand gage, die ze ten eenenmale verwaarloosde moest ze uit eigen beurs betalen of werd voor hun prijs op zijn rekening gedebiteerd ${ }^{2}$. Het verleggen, versteken of verwerpen van eenig gereedschap van timmerlui, stuurlieden, busschieters, koks of chirurgijns werd gestraft met laarzen voor den mast. Die zonder bevel van den gezagvoerder grof geschut losbrandde verbeurde een maand gage. Officieren, die de hun opgelegde zorg voor de dagelijksche en wekelijksche reiniging van het schip verzuimden, werden getroffen met het verlies van twee maanden gage ${ }^{3}$. Niemand mocht "zijn gevoeg doen» of "zijn water lossen» dan op de daarvoor aangewezen plaats, "noch ook, zijn kleederen nat gemaakt hebbende, die zonder uit te trappen in het schip laten liggen» op boete telkens van tien stuiver. Tot verhoeding van de "vele ongelukken,» die uit het dobbelen en spelen voortkwamen, was voorgeschreven dat niemand binnen scheepsboord brengen of maken mocht "eenige dobbelsteenen, kaartspel of andere instrumenten daartoe dienende, 》 op straffe van acht dagen lang te water en te brood in de boeien te worden gezet; die ze gebruikte werd beboet met twintig stuiver telkens en verloor het spel, dat overboord werd geworpen. Bovendien behoefden schulden, met spelen of wedden gemaakt, niet te worden voldaan en was de winner

1 Hoe het laarzen geschiedde wordt beneden (blz. 527) uiteengezet.

2 Deze laatste bepaling alleen in den artikelbrief van 1742 , in de oudere komt zij niet voor.

3 Als voren. 
gehouden ze aan den verliezer te restitueeren. Op dronkenschap stond een boete van een maand gage telkens en "daarenboven na gelegenheid van zaken gestraft te worden» ${ }^{1}$, op het maken van quaestie laarzen door het kwartier. "Zoo wie plukhaart of met vuisten slaat (luidde het verder) zal drie dagen te water en te brood in de ijzers geslagen worden, en wie eenig mes trekt met toorn om iemand leed te doen of te kwetsen, zal met een mes door zijn hand aan den mast genageld worden en aldaar zoo lange staan totdat hij hetzelve doortrekt, en iemand kwetsende zal gekield worden en daarenboven zes maanden gage verbeuren. En zoo wie iemand doodde, zal met den doode levend overboord gezet worden en zijn maandgelden verbeuren». Wanneer iemand zonder verlof van den gezagvoerder met vuur of licht in het ruim, de scheepsbottelarij of kruitkamer ging wachtte hem, behalve arbitrale correctie naar gelegenheid van zaken, een boete van een maand gage. Voorts was op dezelfde boete bepaald dat niemand tabak mocht «koopen of mangelen ${ }^{2}$ noch ook denzelven nuttigen anders als bij dage en met consent en kennisse van den kapitein, schipper of gezaghebber en dat alleenlijk op het boevenet en vóór den grooten mast». Ook stond het niemand vrij "brandende lonten, kaarsen of ander vuur, hoe dat genaamd kon worden, te gebruiken of bij zich te dragen, ten ware tot haar ambt en scheepsbehoeftens en dat met kennisse van de officieren, alles op poene van acht dagen in de ijzers te zitten en daarenboven nog een maand gage te verbeuren, hetwelk pertinentelijk moest worden aangeteekend, en zoo wie hierin verzuimelijk ware, die moest verbeuren gelijke boete, van welke boete de provoost zou hebben en genieten den zesden penning». Die van boord voeren anders dan met toestemming van den kommandeerenden officier of aan land of in andere schepen bleven overnachten zonder verlof daartoe te hebben ontvangen, werden arbitraal gestraft. Insgelijks was het verboden om, als men in eskader voer, zonder uitdrukkelijk bevel van den opperbevelhebber der vloot van den eenen bodem op den anderen te gaan: wie in dezen

1 In de artikelbrieven van 1619 en 1634 werd op dronkenschap verbeurte van een maand gage gesteld en daarenboven naar de gelegenheid van de zake gestraft te worden, die van de kajuit vervielen in dubbele boete.

.2 Ruilen. 
misdeed verbeurde telkens een maand gage. ${ }^{1}$ Maakte iemand na bezette wacht geraas of getier of verliet hij de hem aangewezen plaats, dan werd hij "als ongehoorzame aan den lijve als anders» getuchtigd ${ }^{2}$. Mede aan lijfstraf onderworpen waren de wachters, die iemand zonder vergunning aan boord lieten komen. Die zonder verlof van zijn officieren een kooi of slaapplaats innam of daar hooi of stroo in had, verloor een maand gage en moest ze bovendien ontruimen. Officieren die toelieten dat aan de onbevaren personen op de hoogte van de Sorlingsof Scillyeilanden de zeedoop werd toegediend ${ }^{3}$, moesten zooveel maanden gage laten vallen als er personen gedoopt waren, en die dit doopen hadden gedaan of gepoogd hadden het te doen, moesten arbitralijk aan den lijve gestraft of in hun maangelden beboet worden naar gelegenheid van zaken. Indien iemand een gevangene voorzag van spijs, drank of iets anders, werd hem een boete opgelegd van een maand gage alsmede opsluiting in de boeien te water en brood voor acht dagen. Wie den provoost bij een inhechtenisneming verhinderden of aan een door hem gearresteerde hulp boden, moesten lijfstraf ondergaan, en evenzoo met lijfstraf en bovendien nog met verlies van vier maanden gage werden gestraft $z i j$, die zich verzetten tegen "het uitvoeren of executeeren van de justitie of derzelver vonnis». Personen, die den rechter wegens een tegen hen uitgesproken vonnis beleedigden of lasterden, moesten blootshoofds, met gebogen knieën en gevouwen handen God en de justitie en den beleedigden rechter om vergiffenis bidden, terwijl hun voorts "op zekere groote poene verboden moest worden hetzelve meer te doen» en zij bovendien ter beslissing van den Raad in een boete moesten worden geslagen ten behoeve van de Armen ${ }^{4}$. Naast de straffen stelden de artikelbrieven ook een belooning vast voor wie een samenzwering of muiterij aan het licht bracht, te weten ontheffing van straf en een premie van twintig realen van achten als de aangever er

1 Artikelbrieven van $1619,1634,1658$ en 1672. In dien van 1742 komt de bepaling niét voor.

${ }^{2}$ Deze poenale sanctie komt niet voor in de artikelbrieven van 1619 en 1634.

3 In den artikelbrief van 1634 wordt gezegd op de hoogte van de Barles.

4 Instructiën provoost van Dec. 1622 en de in 1735 en 1788 te Middelburg gedrukte. 
zelf in betrokken was, en een van vijftig realen ${ }^{1}$ als hij er geen part of deel aan had ${ }^{2}$ ).

In hoofdzaak bestonden dus de straffen uit geldboeten, verbeurte van maandgelden ${ }^{3}$, opsluiting in de boeien te water en te brood, kastijding aan den lijve en verlies van het leven. Natuurlijk konden uit kracht van hun bevoegdheid om arbitrale correctie te oefenen, met andere woorden de misdadigers op zoodanige wijze te tuchtigen als zij naar omstandigheden geraden oordeelden, door de scheepsrechters ook nog andere straffen worden opgelegd dan die, welke de artikelbrief met name noemde. Zoo vindt men in het reisverhaal van een Duitscher, die tusschen 1667 en 1682 op een Compagniesschip voer, aangeteekend dat personen, die zich aan de een of andere overtreding schuldig makkten, somwijlen een ganschen dag lang aan de scheepspompen werden gezet of in de grootste hitte een heelen dag zonder eten of drinken boven in den mast moesten zitten ${ }^{4}$. Curieus was de straf, welke in 1626 op het schip Hollandia als arbitrale correctie aan een van de opvarende soldaten werd opgelegd. Dit personage had gedurende de reis "zeer oneerlijk en fieltachtig met zijn vrouw geleefd», waarom hij al eens met haar in de boeien had gezeten, "als wanneer hem van den heer kommandeur en zijn Raad wel expresselijk was gerecommandeerd en gelast met zijn huisvrouw goed huis te houden, het vloeken en zweren te laten, het slaan van zijn vrouw te vermijden en als de andere eerlijke soldaten zoude leven, of dat bij foute van dien arbitralijk gestraft zoude worden *. Niettegenstaande deze waarschuwing echter was hij "in zijn fieltachtig leven voortgevaren en had nu een zekeren tijd lang hem gefingeerd ziek te zijn om door luiigheid in de kooi te mogen blijven liggen, gelijk hij gedaan had. Des daags, als hem iemand kwam aanspreken, had hij zeer flauw gesproken, daarmede te kennen gevende dat hij ziek was, en des nachts zulken regiment met zijn vrouw gehad met vloeken, zweren,

1 In den artikelbrief van 1742 wordt gesproken van 20 en 50 rijksdaalders.

2 Tenzij uitdrukkelijk naar elders is verwezen komen al deze strafbepalingen voor in de artikelbrieven van $1619,1634,1658,1672$ en 1742.

3 De boeten en confiscatiën vervielen volgens den artikelbrief van 1742 aan de Compagnie. De oudere artikelbrieven laten de vraag aan wien zij toekomen onbeslist.

4 David Tappen, Funffzehnjährige Ost-Indianische Reisebeschreibung, Hannover und Wolffenbuttel 1704, S. 208. 
oneerlijk spreken even of hij met den duivel bezeten was, dat daaromtrent bij zijn kooi zwaarlijk iemand om slapen konde. En om te meerder faveurs zoowel uit de kajuit als van anderen te verkrijgen had hij hem geveinsd met den duivel gemeenschap te hebben, daardoor dat zijn vrouw zoo verschrikt was geweest dat zij zwaarlijk bij hem durfde slapen gaan, overmits dat zij hem eens een mes dat hij op zijn keel gezet hadde ontnomen had, daarmede dat hij zeide hem het leven te benemen willen. Voor de tweede maal had hij een schaar op zijn keel gezet om van gelijke te doen, die hem mede van zijn vrouw ontnomen werd, en voor de derde maal een strop om zijn hals gehangen om te laten blijken dat hij hem verhangen wilde, die van zijn vrouw mede stukken gesneden werd». Ook had hij "een bloot rapier des nachts in zijn kooi genomen, daarmede hij zijn vrouw telkens dreigde te doorsteken. Dit had zoo eenige nachten lang gecontinueerd, en zijn vrouw telkens op dusdanige manier uitgescholden: gij h..r, gij varken, gij zeug, gij zijt niet gesteld als andere vrouwen, en meer andere scheldwoorden te schandig om te verhalen. Des daags zeide hij dat hij ziek was en opdat zijn geburen dat beter gelooven zouden, had hij in haar gezicht niet veel willen eten maar telkens zijn gordijntjes toegedaan en daarachter niet alleen zijn (eigen) maar veel van zijn vrouws rantsoen opgegeten en gedronken en nog jongst in zeer korten tijd twee heele kazen, en zoo haast hij gegeten had was hij, zoo hij zeide, weer ziek, en des nachts reed hem de duivel en dreigde hij zijn vrouw telkens den hals af te snijden omdat zij niet gesteld was als andere vrouwen, met meer andere guiterije». Om hem van "zulk een grooten moedwil, die voor God en alle menschen stonk» weer op den goeden weg terug te brengen, namen de rechters het volgende middel te baat: vooreerst zou hem de schaar, het mes en de strop, waarmede hij gedreigd had zich het leven te zullen benemen, aan het lijf gehangen worden, vervolgens moest hij daarmede strengelijk op den naakten rug worden gegeeseld en, wanneer dit afgeloopen was, zou hij met een bout aan het been en de zwabber in de hand moeten gaan zoolang totdat "men zien zou dat hij van den luien duivel ontslagen was»' .

Van de lijfstraffen waren het meest in zwang doorhaling van

1 Vonnis krijgsraad uitgaand schip Hollandia 23 Sept. 1626. 
de hand door het mes, van de ra loopen, laarzen ${ }^{1}$, kielhalen, geeselen en brandmerken ${ }^{2}$. Wanneer iemand wegens het geven van een messteek tot het eerste was veroordeeld, werd zijn rechterhand hetzij in het vel tusschen de beide middelste vingers hetzij midden in het vleesch van de hand door den chirurgijn met een klein mesje of ook wel het eigen mes, waarmede de veroordeelde den steek had toegebracht, tegen den grooten mast genageld en moest hij in die houding blijven staan tot hij zijn hand vrijtrok dwars door het mes heen ${ }^{3}$. Daarenboven werd hem soms nog de verplichting opgelegd om aan den chirurgijn het meesterloon voor den gekwetste en de geleverde geneesmiddelen te betalen ${ }^{4}$. Bij het van de ra loopen, dat gemeenlijk met laarzen gepaard ging, maakte men den gevonniste na hem alvorens zoo veel mogelijk ontkleed en aan handen en voeten gebonden hebben vast aan een touw, waaraan van achter op zijn rug een lange lijn was geknoopt, die door een katrol liep welke aan de groote ra hing. Daarna stiet men hem over boord, heesch hem op tot aan de nok of uiterste spits van de ra, en liet dan eensklaps op het bevel van: "Los allemaal» de lijn schieten, zoodat hij van boven neer in het water plofte. Door het lood, dat men vooraf bij zijn voeten aan het touw had gebonden, zonk hij onmiddellijk en nu heesch men hem, als hij tot zekere diepte was gekomen, wederom omhoog ${ }^{5}$. Was deze dompeling tot driemaal toe her- haald, dan werd hij gelaarsd. Men plaatste hem vóór het ankerspil of vóór den grooten mast ${ }^{6}$, en gaf hem daar, zoo hij soldaat was, met een houten knots van dezelfde gedaante als een geweerkolf of, als hij tot het scheepsvolk behoorde, met een dik touw, de zoogenaamde dagge, twee-, drie-, vier-, vijfhonderd slagen voor "het natte gat» dat hem de huid bont en blauw geschilderd werd en hij in geen dagen zitten

1 Zie beneden blz. 527.

2 Johann Wilhelm Vogel, Ost-Indianische Reisebeschreibung. Altenburg 1716, Vorbericht.

3 Johann Jacob Saar, Ost-Indianische funffzehenjährige Kriegsdienst, Nürnberg 1662, S. 6; Johann von der Behr, Diarium oder Tagebuch, Jena 1668 , S. 17.

4 Sententie in het Scheepsboek van het in 1715 uitgeloopen schip Zuiderbeek.

- Vogel, a. w. S. 541; C. de Jong van Rodenburg, Reize naar de Caribische eilanden in de jaren 1780 en 1781, Haarlem 1807, blz. 16, 17.

6 Sententie uitgaand schip Hollandia 30 Juli 1626. 
kon ${ }^{1}$. Die een buitengewoon ernstig misdrijf pleegden, zich aan den provoost vergrepen bijvoorbeeld of den schipper of een ander officier sloegen, werden gekielhaald. Men bond hun een touw om het lijf dat door blokken was geschoren, welke aan de beide nokken of uiteinden van de groote ra waren genaaid, en onder de kiel door liep. Langs dit touw werd de veroordeelde, na eerst tot op het hemd en den onderbroek ontkleed te zijn geworden en een soort van looden harnas, opzettelijk hiertoe vervaardigd, te hebben aangetrokken, vastgebonden. Daarna bond men op zijn bovenarm een groote met olie gedrenkte spons of lap, stopte zijn ooren met wol, en ried hem aan om, terwijl hij in het water was, sterk op de spons te bijten opdat hij minder zeewater zou binnen krijgen. Men hing nu aan het touw of aan de voeten zóóveel steenen of andere zware voorwerpen, dat hij dieper zinken moest dan de diepgang van het schip bedroeg, heesch hem tot aan de nok van de ra omhoog en liet hem vervolgens op het "Los allemaal» van den schipper in zee vallen. Zoodra hij diep genoeg gezonken was liet men hem aan de andere zijde van het schip eerst langzaam om hem onder de kiel door te halen, en naderhand wanneer men berekenen kon dat hij daar onder heen was vlug naar boven, en herhaalde dit tot driemalen toe. Somtijds gebeurde het dat het bloed den gekielhaalden uit neus en ooren kwam, soms geraakten zij buiten kennis en vielen flauw. Het gevaar waaraan hij bloot stond maakte de straf, op zich zelf. al vreeselijk genoeg, voor den veroordeelde dubbel rreeselijk, want, indien de aangehangen zwaarte bij ongeluk te licht was genomen, liep hij gevaar het hoofd tegen de kiel of het onderschip te pletter te stooten ${ }^{2}$. Meermalen gebeurde het ook dat de overheid een opvarende, die zich aan een buitengewoon zwaar vergrijp had schuldig gemaakt, onderweg ergens aan land zette. Dit overkwam o. a. een hoogbootsman, die op de terugreis van de vloot van Jacob van Neck in 1599 zijn schipper had geslagen. Zij lieten hem op $\mathrm{S}^{\mathrm{t}}$ Helena achter,

1 Vogel, a. w. Vorbericht; de Jong, a. w. blz. 17; Merklein, Ost-Indianische Reisebeschreibung, Nürnberg 1672, S. 936; Von der Behr, a. w. S. 126; Journaal uitgaand schip Zutphen 25 Mei 1632.

2 Vogel, a. w. Vorbericht; Christophorus Frikius c. s., Drie seer aenmereklijeke reisen, Utrecht 1694, blz. 7, 8; Saar, a. w. S. 7. Saar verhaalt hoe hij het in 1647 heeft bijgewoond dat iemand, die niet diep genoeg gezonken was, met verbrijzelden schedel werd opgehaald. 
"hem latende een deel broods, olie, rijst, hoeken om visch te vangen, met een roer en een deel buskruit en zeiden hem alzoo adieu " ${ }^{1}$. Een dergelijk lot trof in 1635 een schieman van den uit Indië terugkeerenden bodem Zutphen, die op hoogen toon uit naam van het scheepsvolk had geeischt dat eenige vrouwelijke passagiers, welke van Gouverneur-Generaal en Raden vergunning hadden bekomen om in de kajuit te eten, daaruit zouden worden verwijderd en door opruiiing van het scheepsvolk te weeg had gebracht dat zij gedreigd hadden de kajuit te zullen overvallen, een plaats, gelijk het vonnis zegt, welke "binnen scheepsboord als een raadhuis in een stad voor heilig en sacrosanct geacht en gehouden moest worden». Ten slotte had hij de onbeschaamdheid zelfs zóóver gedreven, dat hij den schipper toevoegde: "En gij zult mede uit de kajuit met uw vrouw, alle de maats willen het zoo hebben en ik ook, kloppende meermalen op zijn borst even of zijn kwade wille als een wet onder de gemeene maats behoorde stad te grijpen en effect te sorteeren». Altemaal zaken, meende de Breede Raad, "van den allerkwaadsten gevolge, strekkende om andere trouwe en eerlijke soldaten en bootsgezellen tot moedwilligheid en ongehoorzaamheid op te wekken» en die daarom "anderen ter exempel op het rigoureuste» moesten worden gestraft, weshalve hij den misdadiger veroordeelde tot verlies van al zijn verdiende maandgelden alsmede om "aan het Robbeneiland gezet te worden om aldaar alzulke fortuine te verzoeken als hem God Almachtig zou gelieven te verleenen " ${ }^{2}$. Nòg rebelscher gedroeg zich op datzelfde schip Zutphen een van de soldaten, een "principaal belhamel en kakelaar» en "een aandrijver en causa movens van alle moedwilligheden», welke sedert het vertrek van Batavia tot op de aankomst in de Tafelbaai aan boord voorvielen. Zoo zette hij de maats op met te beweren dat men de kajuitsgasten op rantsoen behoorde te stellen, daar de wijn en arak door hen werd verkwist, hoewel bij het opnemen van den voorraad bleek dat zij niets meer genoten hadden dan hetgeen hun toekwam, en hielp hij eens, toen de

1 Tweede Schipvaart der Hollanders naar Oost-Indië in Begin en Voortgang I.

2 Vonnis van den Breeden Raad der retourvloot voor anker liggende in de Tafelbaai 21 Maart 1635. Tot dezelfde straf met driemaal kielhalen bovendien werd door den Breeden Raad der retourvloot op 29 Maart 1636 een van de schepelingen veroordeeld, die aan een samenzwering tot het afloopen van het schip had deelgenomen. 
bottelier ten behoeve van de kajuit een ledig wijnvat moest vullen, ijverig mede om hem dit met geweld te ontrukken. Een anderen keer, toen de overheid hem wegens vechten in de boeien wilde laten sluiten, verzette hij zich hier zóó sterk tegen dat haar bevel eerst met de hulp van eenigen van de voornaamste scheepsofficieren kon worden ten uitvoer gelegd. En, als wilde hij op zijn baldadigheid de kroon zetten, toen de opperbevelhebber van de vloot hem dien dag door een paar gemachtigden op het admiraalschip ter- verantwoording liet roepen, gaf hij "met een stout gebaar en gelaat" botweg ten antwoord, dat hij dit niet verkoos te doen, dat zijn zaak zoo groot en gewichtig niet was of zij kon wel op zijn eigen schip worden afgedaan, en ofschoon de beide gemachtigden hem vermaanden "dat hij zich zou laten gezeggen en naar boord van den admiraal varen zou opdat hij van zijn zaak, die licht en civiel was, geen zware en crimineele acte maken zoude», werd door hem nochtans "wel obstinatelijk geantwoord dat hij niet wilde noch begeerde over te gaan, ten ware hem zulks bij de maats belast en geordonneerd werd, sprekende meteenen de maats aan en met luider kele uitroepende: Wel maats, wat zegt gij, zal ik gaan of niet?»

Het gevolg was dat de gemachtigden noch van hem noch van het scheepsvolk iets gedaan kunnende krijgen ten slotte onverrichter zake moesten terugkeeren. Maar het ergste van alles was de wijze zooals hij optrad tegen den Breeden Raad, die des anderen daags aan boord van de Zutphen op de voorgevallen moedwilligheden orde kwam stellen. Niet alleen toch sloeg hij het bevel om in hun vergadering te verschijnen verachtelijk in den wind: zij moesten, zeide hij, als zij hem wat te zeggen of voor te stellen hadden, zelf maar bij hem boven komen, maar hij hield zich tevens onder de bescherming van de maats, die hij geheel op zijn kant had, maar voortdurend boven, zelfs nadat men hem voor de tweede maal had ontboden. En ook toen hij ten laatste in de vergadering verscheen bleef hij maar aldoor in zijn wederspannigheid volharden, want terwijl die van den Raad hem naar de schuit voerden, welke hem naar het admiraalsschip zou overbrengen, wist hij met een gauwigheid aan hun geleide te ontsnappen, vluchtte naar beneden bij de maats, en liet de heeren tot spot van allen die het aanzagen boven op den overloop staan. Eerst toen hem door den afval 
van de maats alle hoop op uitkomst ontviel, legde hij het hoofd in den schoot en liet zich naar het schip van den admiraal brengen. Daar ontving hij loon naar werken: veroordeeling tot den strop ${ }^{1}$. Behalve ophanging aan den grooten mast ${ }^{2}$ of aan een van de ra's ${ }^{3}$ werd ook wel fusilleering toegepast. Zóó geschiedde, om een voorbeeld te noemen, in 1614 met een soldaat op het schip Amsterdam, die sommigen van zijn kameraden overreed had om aan Kaap Lopo Gonsalves achter te blijven tot zij door eenige eventueel daar aanloopende schepen uit $\mathrm{S}^{\mathrm{t}}$. Jago zouden worden afgehaald. Hij zelf werd verwezen om "geharquebuseerd" te worden, zijn medeplichtigen werden veroordeeld "om voor schelmen van hun respective vendels gecasseerd, het geweer ${ }^{4}$ voor de voeten gebroken en elk driemaal gekielhaald en van hun korporaalschap voor den mast gelaarsd te worden $»^{5}$. Levend over boord geworpen werden zij, die een doodslag begingen, zich aan homosexueele of zoogenaamde stomme zonde schuldig maakten ${ }^{6}$, of het schip wilden afloopen, zooals onder andere in 1636 op de Frederik Hendrik plaats had, waar niet minder dan negen man van de equipage een samenzwering op het touw hadden gezet om, zoodra men beoosten de Kaap de Goede Hoop zou aangekomen zijn, alle officieren en minderen, die geen gemeene zaak met hen wilden maken, om het leven te brengen en den bodem voor geld in handen van den vijand te spelen ${ }^{7}$. Uit een merkwaardige sententie, op de retourvloot van 1634 uitgesproken, blijkt dat men somwijlen door het lot liet uitmaken wie van de veroordeelden de doodstraf zou ondergaan en wie bij manier van genadebewijs met een lichtere zou vrijkomen. Aan boord van

1 Vonnis Breede Raad en Krijgsraad der retourvloot voor anker liggende in de Tafelbaai 20 Maart 1635.

${ }^{2}$ Vogel, a. w. Vorbericht.

3 Journaal uitgaand schip Amsterdam 8 April 1635.

4 Dat is: wapenen in het algemeen. Een haakbus was een soort van vuurroer.

${ }^{5}$ Brief van Gerard Reijnst aan de kamer Amsterdam van voor Kaap Lopo Gonsalves 25 Januari 1614.

6 Brief van Artus Gysels aan als voren uit de Tafelbaai 6 Sept. 1630; Christophorus Frikius, Elias Hesse en Christophorus Schweitzer, Drie seer aenmercklijcke reijsen, Utrecht 1694, blz. 109, 343.

7 Vonnis Breede Raad der retourvloot 29 Maart 1636. Op het schip Zclandia werden in 1613 eenige opvarenden, die het schip hadden willen afloopen, gevonnist om ,elk met een schuiftange aan het lijf gebonden levendig als verraders over boord gezet te worden" (Brief van Hendrik van Waterford c. s. aan de Bewindhebbers uit Bantam 31 Dec. 1613.) 
een van de schepen dier vloot namelijk werden in Juni 1634 een vijftal personen berecht, die allerlei daden van muiterij, oproer en geweld hadden bedreven. $\mathrm{Zij}$ hadden in de eerste plaats vermeerdering van rantsoen willen afdwingen en, toen zij daarop van de overheid ten antwoord kregen dat zij hun verzoek ter eerste gelegenheid aan den opperbevelhebber zou overbrengen, staande gehouden dat men dezen daar niet in behoefde te kennen. $\mathrm{Na}$ van een opvarend passagier wijn en arak te hebben gestolen, waren zij vervolgens half beschonken op de kajuit gekomen, hadden den schipper buiten geeischt, hem uitscheldende "voor eenen hond, schelm en reu en dreigende dat zij hem, als hij buiten kwam, met brandhouten "den kop zouden inslaan", hadden onderwijl de brandhouten in het kajuitsportaal gesmeten en waren daarop naar de hut van de stuurlieden gegaan, waar zij de deur met een windboom open liepen en een paar opvarenden verscheidene messteken toebrachten. Den volgenden dag door den vollen Raad ter verantwoording gedaagd, hadden zij eerst niet willen binnenkomen en eindelijk "met ongestelde en brutale minen compareerende de obedientie aan haar overheid en justitie geweigerd». Een hunner stelde zich daarbij zoo driest aan, dat hij "met een bloot mes, schuilswijze hetzelve in zijn slinkerhand houdende, ter vergaderinge van zijn overheid compareerde", en beroemde zich, zoodra hij weer boven kwam, "dat hij van meeninge was geweest die hem om vast te zetten had willen aantasten zich in een hoek pal gezet en dien man zoo gesteken en gesneden zoude hebben, dat hem de darmen op de schoenen zouden hebben gevallen». Een ander had bovendien op zekeren dag den schipper met "vileine bejegeningen en onlijdelijke scheldwoorden aangerand» en geslagen en dit eenige weken later opnieuw gedaan. Naderhand was hij, bij gelegenheid dat de opperbevelhebber der vloot eens met zijn schip «binnenroeps» langs het hunne voer, in de blinde mars geklommen en had den vlootvoogd van daar uit gescholden "hem noemende Pharao, Ducdalf en andere zeer goddelooze blasphemiën uitspuwende», alles zoo het scheen om het volk van het admiraalsschip al mede tot oproer en muiterij op te hitsen. Een derde had, zoolang de reis duurde, telkens wanneer de schipper het een of ander scheepswerk ordonneerde, altoos tegen gesproken, ja toen de schipper de maats gelastte het schip te spoelen hem 
brutaalweg toegebeten: "Schipper, wilt gij op de stelling staan en water slaan, zoo willen wij het schip spoelen. Gij hebt ons nu niet meer, wij zijn uit Indië». Dat deze manier van doen geenszins uit een voorbijgaande vlaag van onbesuisde drift doch louter uit welbewuste zucht tot verzet voortkwam, leed naar het inzicht van de rechters geen twijfel. Of had hij niet nog kort geleden den bottelier overgehaald om aan een paar visschers, die verversching aanbrachten, in plaats van twee, gelijk van hoogerhand bevolen was, vier zakken rijst te geven en, toen hij over dit feit door den schipper onderhouden werd, dezen niet onder allerlei scheldwoorden de vraag voor de voeten geworpen of hij, schipper, dan soms bang was «zijnen balg niet vol te zullen krijgen», daar nog met een spijtigen mond aan toevoegende "dat hij met het knorren van den schipper niets te doen had» en dergelijke woorden meer? Gezwegen nog dat hij "met zijn consorten op zijn eigen houtje en fantasije, buiten kennis of weten zijner overheid, de scheepsvarkens had doen slachten en verdeeld had». In één woord gezegd, de vijf schuldigen hadden in hun brooddronkenheid het eene misdrijf op het andere gestapeld: het vonnis sprak in één adem van 'publieke mutinatie, geweld, seditie, vertreding van hun wettige overheden, violatie van de justitie, overtreding van den generalen en algemeenen artikelbrief en meineedigheid». Dat de uitspraak van de rechters daarmede in overeenstemming was, spreekt van zelf. $\mathrm{Zij}$ werden veroordeeld om "met hun vijven het lot te trekken met drie blanke en twee geteekende briefjes, en de twee personen, die de rechtvaardige God het lot te beurte zendt, gebonden aan handen en voeten over boord te zetten en in het water te straffen dat er de dood nạ volgt met verbeurte van al hare gagiën en goederen, item die bij lotinge drie vrijgetrokken personen gebannen te "moeten gaan en blijven op de galeie, met gelijke verbeurte van al hare gage en goederen ${ }^{1}$.

Allen, die het scheepsleven bij ervaring kenden, waren het eens dat zonder zulke gestrenge, om niet te zeggen zulke barbaarsche straffen, aan geen instandhouding van orde en

1 Sententie Breede Raad retourvloot 24 Juni 1634. Dezelfde rechtsoefening bij loting had in de $17^{\text {de }}$ eeuw òok herhaaldelijk bij de landmacht plaats, vgl. Militaire Spectator 1889, blz. 117. Een doodvonnis tot de galg bij loting wordt ook vermeld door Brandt, Leven van de Ruijter, blz. 361. 
tucht viel te denken. Er bestond nu eenmaal geen bandeloozer dier, getuigt een reiziger, die omstreeks 1711 op een Compagniesschip naar Indië ging, dan een matroos. "Het is waar (zegt hij), zoolang de storm woedt, kunnen zij het hoofd laten hangen als een geknakte bieze, maar nauwelijks is het gevaar geweken of vloeken, zweren, hoereeren, uitspatten en moorden zijn voor hen maar bagatellen. Daardoor is er aan boord onder deze kerels altoos wat aan de hand, en zaten de officieren hun niet zoo scherp met straffen achterna, zij zouden onder dat ruwe gespuis hun leven geen oogenblik zeker zijn» ${ }^{1}$. Matrozen en soldaten, aldus een auteur van een dertig jaar vroeger, "woeden als wilde zwijnen; hare monden staan opgesperd als eenen oven tot het uitgieten van lasterlijke woorden, ja practiseeren door hun boos bedrijf uit oorzake van alle natiën onder den anderen ${ }^{2}$ dat de vloeken, die ieders land snood genoeg zijn en in eigen gebruik hebben, te zamen als een pottagie in een ketel van duivelsche vonden gekookt worden; zij rooven en stelen, drinken en hoerjagen zoo schandig, dat het bij hen geen schande schijnt te wezen", daarom, voegt hij er bij, moeten zij met strenge tucht worden geregeerd "als onwillige beesten, anders zouden zij iedereen aanranden door hun moedwil ${ }^{3}$.

De baldadigheid en de dieverijen, die met vechten, schelden en vloeken tot de meest voorkomende overtredingen behoorden, begonnen alreeds vóór men het zeegat uitliep. Wie het zelf niet heeft bijgewoond, verklaart iemand uit het laatst der $18^{\text {de }}$ eeuw, kan zich geen denkbeeld vormen van «het onzinnig vloeken, bulderen, schoppen en slaan» als het volk aan boord komt ${ }^{4}$. Niets was meer gewoon dan dat de bevaren gasten de drukte en het gewoel, waarmede het inladen van de bagage gepaard ging, te baat namen om uit den berg van kasten, kisten en kooien, die in de meest chaotische wanorde dooreen lagen ${ }^{5}$, een kooi of kist weg te sleepen, bij voorkeur van dezen

1 Ernst Christopher Barchewitz, Ost-Indianische Reisebeschreibung, Erfurt 1751 , S. 661 .

2 D. i. doordien zij uit volk van allerlei natiën en tongen zijn samengesteld.

s $P$. van der Burg, Curieuse beschrijving van verscheide Oostindische gewesten, Rott. 1677. blz. 19.

4 J. Harger, Verhandeling over de besmettelijke rotkoortsen op de uitgaande Oostindische schepen, Middelb. 1784, blz. 356, 357.

5 Jörg Franz Müller's Reisindrukken, ed. Heeres in De Navorscher 1902 blz. 14 . 
of genen nieuweling, die zij ergens in een verborgen hoek openbraken en geheel uitplunderden ${ }^{1}$, terwijl de bestolene, zelfs al wist hij hen met name te noemen, somtijds maar liever dan de schuldigen aan te geven stil zweeg om onderweg niet in nog grooter ongelegenheid te komen ${ }^{2}$. Vooral loerden de oudere varensgezellen op zulke reisgenooten die, na "van drinken, klinken, spelen enz. hun dagelijksch ambacht gemaakt te hebben », totaal aan lager wal waren geraakt en nu eindelijk, als laatste toevlucht van zoo veel verloren zoons, voor koloniaal naar Indië gingen. Onbekommerd over den dag van morgen bleven dezen in het begin aan boord hun leventje van vroolijke Frans voortzetten, lustig opschaffende van de provisie, die zij in hun kist hadden medegenomen, alsof er geen einde aan komen kon. Nauwelijks hadden "de oude likkepannen» dezulken in het oog gekregen of zij voegden zich allerminzaamst bij hen om door hun welwillende medewerking "het einde des vermaaks te volbrengen», anders gezegd hun laatste beetje "brandewijn, tabak en peperkoek» vriendschappelijk te helpen opsnoepen ${ }^{3}$. Het gevolg was dat, als de gulle gastheeren eenige weken na dien geen extra-versnapering meer bezaten bij hun rantsoen en op den koop toe nog van de anderen werden uitgelachen ${ }^{4}$, de vriendschap van voorheen al te spoedig omsloeg in bittere haat en vijandschap.

Niets gaf echter meer aanleiding tot twist en tweedracht dan het samenleven van soldaten en matrozen op éénzelfde schip. Want volgens een oudgèdiende, die ze op zijn Oostindische reizen van 1694-1701 door eigen ondervinding had leeren kennen, was het niet te zeggen welk een felle antipathie er tusschen die beiden aan boord heerschte. "Als zij niet verder kunnen komen," schrijft hij, "sarren zij elkander met bijnamen, de matrozen noemen namelijk de soldaten slothouten, dat zooveel beteekent als stukken hout die maar op één plaats van het schip te gebruiken zijn ${ }^{5}$, de soldaten van hun kant

1 Harger, t. a. p.; Scheepsboek uitgaand schip Sparenrijk (vonnis 28 Maart 1749); Von Wurmb en Von Wolzogen, Briefe, Gotha 1794, S. 35.

${ }^{2}$ Barchewitz a. w. S. 43.

3 Van der Burg, a. w. blz. 3.

4 Van der Burg, t. a. p.

5 Slothouten noemt men de vierkante ijzeren bouten, welke in het onderste gedeelte van de stengen zijn aangebracht en waarmede deze op de lang. zalings rusten. 
schelden de matrozen uit voor bakpooten en slangevellen, en zoo men op de schepen niet zulk een strenge discipline hield zouden beide partijen elkander menigmaal in de haren vliegen ${ }^{1}$. Dat deze vijandschap niet van heden of gisteren was, toont het schrijven van een hooggeplaatst Compagniesdienaar, die in 1630 uit zijn schip aan de Bewindhebbers berichten moest: "ik bespeure dat de oude passie nog regneert, dat is dat de matrozen doodvijanden van de soldaten zijn» ${ }^{2}$.

Alsof dit alles voor de verstoring van de rust geen stof genoeg opleverde, kwam daar nu en dan nog de moeite bij en de last, welke men van de vrouwelijke passagiers ondervond. "Wat belangt het gouverneeren van de vrouwspersonen» op onze reis "bijzonder van de jonge dochters, daarvan waar wonder te verhalen», zoo schrijft in 1624 een pas te Batavia aangekomen Compagniesdienaar aan de Bewindhebbers, "doch God lof alles is met zoo goede ordre, opzicht en eenigheid toegegaan dat ik niet en twijfele of Uwe Edelen zullen een welgevallen daaraan hebben». Evenwel, de_officieren "haddeen" "moèite genoeg gèhad», verzekert hij, om een paar dames tot verzoening te brengen, tusschen wie "wat jaloezie en oneenigheid om vrouwedifferentie» was geweest, en ten slotte moet hem toch de verklaring van het hart: «ik dank God dat dat cargasoen zoo wel geconditioneerd is aan de markt gebracht, men zoude $^{\mathbf{3}}$ mij voorwaar met diergelijke koopmanschappen na dezen niet meer voorzien of de hoogdringende nood zoude zulks vereischen" ${ }^{4}$. Wanneer iemand, die toch over het geheel geen reden tot groote klachten had, zulk een verzuchting slaakte, hoe zal het dan wel den Gouverneur-Generaal Jacques Specx te moede zijn geweest, die reeds een week nadat hij in Januari 1629 uit Texel was uitgezeild, met de vrouwlui op zijn vloot zooveel te stellen had, dat hij aan de Bewindhebbers schrijven moest: "het volk is altezamen wel dispoost, niet meer gebrekende als veel eerlijke dochters en huisgezinnen in plaatse van zooveel vuile voddens en straatvarkens als er in alle schepen, God beter het, gevonden worden,

1 Christoph Langhansz., Neue Ost-Indische Reise, Leipzig 1705, S. 26, 27.

2 Brief van Artus Gijsels uit het schip Deventer in de Tafelbaai aan de Kamer Amsterdam 6 Sept. 1630.

3 D. i. behoorde.

4 Brief van Pieter Janszoon Muijser aan de kamer Amsterdam uit Batavia 28 Januari 1624. 
daarvan dat er zoo vele en van zulken aard zijn dat ik het mij schame vorder openinge daarvan te doen. ${ }^{1}$.

Van geen beter gehalte waren die vrouwelijke passagiers, welke door een listigen vond op de uitgaande schepen wisten te geraken, voor het meerendeel wijven en deernen uit de laagste heffe van het volk die, omdat zij wegens hun ergerlijk levensgedrag van ieder werden verfoeid of wel omdat zij iets op hun kerfstok hadden bij de justitie, het in het Vaderland te benauwd kregen en nu in Indië of aan de Kaap, waar men naar hun verleden geen al te nauwe navraag deed, hoopten vooruit te komen door een goed huwelijk ${ }^{2}$. Zoo nam in 1643 een vrouwspersoon, die zich in manskleeren had gestoken, onder een valschen naam dienst bij de Compagnie om, gelijk zij naderhand voorgaf, haar man in de Oost te gaan opzoeken, van wien zij in geen tijden iets vernomen had. $Z_{i j}$ mocht echter haar hartewensch niet vervuld zien, want bij zekere gelegenheid door een al te overvloedig gebruik van brandewijn van de streek gebracht begon zij voor een manspersoon zoo vreemd te doen dat het ieders achterdocht opwekte. Men liet daarom de schippers- en de predikantsvrouw oculaire inspectie doen en nu kwam het bedrog, dat zij zes weken lang uitstekend had weten te verbergen, aan het licht. Het einde van de geschiedenis was dat zij van de reede bij Rammekens, waar het schip nog voor anker lag, aan wal werd gebracht en in het Middelburgsche spinhuis eenige maanden lang vrije huisvesting verkreeg ${ }^{3}$. In April 1770 , omtrent drie weken nadat het in zee was gestoken, kwam men op het schip Schoonzicht tot de ontdekking dat zich onder de soldaten een vrouw bevond. Het was een boerendochter uit het Oldenburgsche die, wegens slechte behandeling uit haar geboorteland weggetrokken, te Hamburg in aanraking was gekomen met een Hollandsch werfofficier, die haar allerlei moois vertelde van de schoone kans die zij had om in Indie haar fortuin te maken en door wien zij zich ten slotte had laten medetronen naar Rotterdam, alwaar zij zich op zijn raad in manskleeren vermomd hebbende op het Oost-Indische Huis dienst genomen had als koloniaal. Daar men bij de ontdekking

\footnotetext{
1 Brief van Jacques Specx aan de Kamers Amsterdam en Middelburg uit het schip Hollandia liggende ter reede van Duins 1 Febr. 1629.

2 Nicolaas de Graaff, a. w. blz. 14; Langhansz, a. w. S. 6.

s Von der Behr, a. w. S. 8.

Dl. 67. 
van het bedrog te ver in zee was om haar uit het schip te verwijderen, werd zij medegenomen tot aan de Kaap, waar men haar aan land bracht om haar met de eerst aanloopende retourschepen naar Holland terug te zenden ${ }^{1}$.

Anderen weer poogden zich ergens op een schip te versteken en onder dezulken waren er, die zich om zoo te spreken met geen stokken lieten wegslaan. Op het schip Arentsduijn, dat in April 1712 uitzeilde, haalde men twee dagen vóór het vertrek de vrouw van den konstapel voor den dag. Ofschoon zij op last van de Bewindhebbers aan wal werd gebracht en de schipper "na dien tijd om het aan boord komen te beletten van die en andere vrouwen, die haar mochten willen versteken, continueel zoo bij dag als nacht twee schildwachten totdat in zee zijn geraakt achter op de kampanje had gesteld», - toen men goed en wel in het ruime sop kwam bleek het dat diezelfde konstapelsvrouw zich niet ontzien had "op een zeer assurante en heimelijke wijze in manskleederen haar ten tweeden male aan boord te vervoegen en op dezen bodem te versteken ${ }^{2}$. Gelukte het zulke "verstekelingen» zich aan boord schuil te houden totdat men in volle zee was gekomen, dan voegden zij zich als manskerels verkleed onder de maats, spijsden met hen aan één bak, sliepen zoo goed als de matrozen en soldaten in een kooi, speelden in een woord hun rol naar alle regelen van de kunst. Wie op deze wijze onopgemerkt tot Batavia doorglipten, stonden wel bloot aan het gevaar, dat zij bij hun aankomst aldaar in de val liepen en bij den kop werden gevat om met de eerste de beste scheepsgelegenheid naar Holland terug te worden gestuurd ${ }^{3}$, maar van hen had men ten minste aan boord niet meer last dan van anderen. Diegenen, wier bedrog onderweg uitkwam, werden weer in een vrouwenpakje gestoken en ten behoeve van dezen of genen van de officieren aan het verrichten van naai- en waschwerk gezet. Doch dezen gaven nu ook, gelijk men denken kan, door hun aanwezigheid gedurig aanleiding tot verstoring van orde en rust: zij behoefden met den een maar wat gemeenzamer te wezen dan met den ander

1 J. S. Stavorinus, Voyages to the East Indies, London 1798, I p. 195; Scheepsboek van het schip Schoonzicht 30 April 1770.

2 Scheepsboek van het schip Arentsduijn (resolutie Scheepsraad van 1 Mei 1712).

3 Barchewitz, a. w. S. 625 . 
om onder het volk de grootste jaloerscheid en oneenigheid te verwekken '

Het ergst van al plachten de moedwil en baldadigheid te woeden op de thuisreizen. Wanneer men onder de vaderlandsche kust kwam was het somwijlen met alle ontzag voor de bevelen van de meerderen gedaan. Men haalde den koksketel aan dek om dien in duizend gruizelementen te slaan, brak met geweld de bottelarij en de victualiekamer open, smeet de arakvaatjes in zee, hield in het kort zoo allerontzettendst huis alsof er in plaats van menschelijke wezens een troep dolle honden aan boord was ${ }^{2}$. Ziehier een tooneel, dat zich in 1701 afspeelde op een retourschip, naar het leven afgeschilderd door een die het als ooggetuige had bijgewoond. "Onze kok, niettegenstaande hij zich verstoken had, moest voor den draad komen, zij legden hem over de geheel met rookzwart bedekte ketels en sloegen hem met schuimspanen ${ }^{3}$ en lepels zoo onbarmhartig voor zijn achterste, dat hij er geruimen tijd lam van bleef en niet in staat was om op het Oost-Indische Huis zelf zijn kist en gage af te halen. Kortom men schaamt zich al den moedwil te vermelden, dien zij bedrijven. Kommandeeren geldt daar voor niets meer. De schipper dorst zich niet te laten zien en werd in zijn gezicht, terwijl de Bewindhebbers die ons afdankten er bij stonden, uitgemaakt voor een schelm, een rantsoendief en een menschenplager, en gedreigd dat men het hem aan den wal naar verdienste betaald zou zetten, zooals naderhand ook te Middelburg geschied is, waar zij hem bijkans krom en lam sloegen ${ }^{4}$.

Wat was natuurlijker overigens dan dat de terugkeerende bootsgezellen en soldaten, nu zij niet langer gelijk in Indië ${ }^{5}$ en op de uitreis in bedwang werden behouden door de vrees van naar de eene of andere "bandietenplaats» te worden gezonden, hun woede zochten te koelen aan een ieder die hun wrevel had opgewekt, aan de schippers in de eerste plaats, van wie de meesten berucht waren om de "rouwe en harde manier»,

1 Nicolaas de Graaff, a. w. blz. 14.

2 Langhansz, a. w. S. 36. Vgl. ook Frikius, Hesse en Schweitzer, Drie seer aenmercklijcke reijsen, Utrecht 1694 , blz. 164 .

3 De Duitsche tekst heeft: Kellen.

4 Langhansz, a. w. S. 651.

5 Vgl. hierroor blz. 532. 
waarop zij hun ondergeschikten behandelden ${ }^{1}$, die vaak uit schraapzucht de voorgeschreven rantsoenen willekeurig verminderden $^{2}$ en door hun tiranniek geplaag het toch reeds zoo ellendig leven van het volk tot een slavenbestaan makten ? ${ }^{3}$

1 Memorie van de Bewindhebbers gecommitteerd tot de uitgaande schepen 1 Nov. 1697.

2 Pieter van Dam, Beschrijving van de Oost Indische Compagnie, Boek I, Deel I, Capittel 17; Johann Schreyer, Neue Ost-Indianische; Reiszbeschreibung, Leipzig 1681, S. 10.

${ }^{3}$ Langhansz, a. w. S. 16; Nicolaas de Graaff, a. w. blz. 22. 